\title{
İlişkisel Sözleşmeler Bağlamında Vatandaş Güveni ve Devlet Bütçesi: OECD Ülkeleri ve Türkiye Karşılaştırması
}

\author{
Ayşe ATILGAN YAŞA*
}

\author{
Kâmil TÜĞEN**
}

\begin{abstract}
$\ddot{O} Z$
Bütçe, esas olarak, vatandaşlar ve devlet arasında yapılan bir çeşit sözleşmedir. Günümüzde devlet bütçeleri diğer sözleşmeler gibi birtakım düzenlemeler gerektiren unsurları barındırmaktadır. Bu bakımdan, bütçe uygulamalarının seyrini ve performansını etkileyen en temel unsurlardan biri de, bütçe hakkın yürütme gücüne emanet eden vatandaşın güvenidir. Son yıllarda pek çok ülkede devlete ve kamu kurumlarına karşı duyulan güvenin azalması, devletin ve kurumların meşruiyetini etkilemekte ve kamusal hizmetlerin kalitesini zedelemektedir. Bu kapsamda çalışmanın amacı, Türkiye'de ve OECD üyesi ülkelerde vatandaşların devlete ve kamu kurumlarına ne derece güvendiklerini ve bu güvenin bütçe göstergelerine ne derece yansıdiğını ortaya koymaktır. Çalışma kapsamında yapılan karşslaştırmalarda OECD veri setinden yararlanılmışıır.
\end{abstract}

Anahtar Kelimeler: Devlet Bütçesi, Bütçe Sözleşmesi, Güven, Vatandaş Güveni, Devlete Güven.

JEL Sinıflandırması: $H 6, H 1, A 13, H 11$.

\section{Relations of Citizen Trust and Government Budget in Context of Relational Contracts: The Comparison of OECD Countries and Turkey}

\begin{abstract}
The budget is mainly an agreement between citizens and the government. Today government budgets, like other conventions, contain elements that require regulations. In this context, one of the most important factors affecting the course and performance of budget implementations is the trust of the citizen who has entrusted the budgetary power to the execution of the budget right. In recent years, the decline of the trust to the government and public institutions in many countries affects the legitimacy of the government and institutions and undermines the quality of public services. In this context the purpose of the study reveal the citizens of OECD member countries and Turkey whether they trust or not to the government and public institutions and this trust to what extent budget indicators. OECD data set was used in the comparisons made within the scope of the study.
\end{abstract}

Key Words: Government Budget, Budget Agreement, Trust, Citizen Trust, Trust in Government.

JEL Classification: $H 6, H 1, A 13, H 11$.

\section{GíRiş}

Güven, vatandaş ile devlet arasında kurulabilecek en sağlam ilişkidir. Karşılıklı güven duygusunun gelişimi için gereken unsurların yerine getirilmesi

\footnotetext{
* Dr. Öğr. Üyesi, Manisa Celal Bayar Üniversitesi, Salihli İktisadi ve İdari Bilimler Fakültesi, Maliye Bölümü, Bütçe ve Mali Planlama Anabilim Dalı, Türkiye, ayse.yasa@ cbu.edu.tr, ORCID bilgisi: 0000-0001-8890-0553.

** Prof. Dr., Dokuz Eylül Üniversitesi, İktisadi ve İdari Bilimler Fakültesi, Maliye Bölümü, Bütçe ve Mali Planlama Anabilim Dalı, Türkiye, kamil.tugen@deu.edu.tr, ORCID bilgisi:0000-0002-7479-2608.
} 
önemlidir. Bu doğrultuda, devlete ve kurumlara karşı duyulan güven düzeyi, vatandaşların topluma aidiyeti ve toplum bilinci, yararlandıkları kamusal hizmetlerin finansmanına katılımı ve kurumların performansı gibi pek çok alanı etkilemektedir.

Bir devletin varoluşu ise, genel anlamda iki temel noktada ele alınabilmektedir. Birincisi, sosyal, siyasal ve ekonomik göstergeler iken diğeri, devleti bir araya getiren vatandaşların devlete yönelik psikolojik algılarıdır (Nettle, 1968'den aktaran Almond, 1988: 856). Bir diğer ifade ile farklı özellikleri ve amaçları olan kurumlardan oluşan devletin niteliğine dair temel prensip, bir devletin vatandaşlarının can ve mal güvenliği başta olmak üzere sosyal, siyasal ve ekonomik haklarını gözetip gözetemediği ve kamu kurumlarının meşruiyetinin gerçekleştirilip gerçekleştirilemediği sorgulamasıdır. Son yıllarda vatandaşların kamu kurumlarına duydukları güvende azalma söz konusudur (Lee ve Schachter, 2019: 406). $\mathrm{Bu}$ anlamda vatandaşların güven düzeyleri hükümetlerin onlar için doğru olan kararları vermediğini düşündüklerinde azalırken, uygulanan politikalarda bütünlük, uygulamacıları dürüst, devleti kurumsallaşmış gördüklerinde ve alınan kararlara katılımları doğrultusunda yükselmektedir (Wang ve Van Wart, 2007: 276).

Kamu gelirleri ve kamu harcamaları miktarının belirlendiği devlet bütçesinin vatandaşın güveni ve katılımı doğrultusunda yönetilmesi gerekmektedir. Vatandaş tarafından duyulan güven kamu kurumları ya da fonksiyonel kamu harcamaları temelinde ele alındığında, hükümet değişimleri, ekonomik ve mali krizler, dünyadaki gelişmeler doğrultusunda toplum yapısındaki farklılaşmalara bağlı olarak ülkeden ülkeye değişebileceği gibi aynı ülke içinde yıllara göre de değişiklik gösterebilmektedir. Bu çalışmada, devlet bütçesinin bir sözleşme niteliği taşıdığı gerçeğinden yola çıkılarak, ilişkisel sözleşmeler bağlamında güven ve bütçe ilişkisi ele alınmış, Türkiye ve OECD ülkelerinde güven ve bütçe ilişkisi göstergeler ışı̆̆ında karşılaştırmalı olarak incelenmiştir. $\mathrm{Bu}$ bağlamda çalışmanın amacı, Türkiye'de ve OECD üyesi ülkelerde vatandaşların devlete ve kamu kurumlarına güven düzeylerini ve söz konusu bu güvenin devlet bütçesine yansımalarını ortaya koymaktır. Çalışma kapsamında ilk olarak devlet bütçesi mali, sosyal ve performans sözleşmeleri çerçevesinde ele alınmış, vatandaş güveni devlet bütçesi ile ilişkilendirilmiş ve söz konusu bu ilişki üzerinden Türkiye ve OECD üyesi ülkelerdeki duruma karşılaştırılmalı olarak yer verilmiştir. Yapılan bu karşılaştırmalarda ise OECD veri setinden yararlanılmıştır.

\section{TOPLUM SÖZLEŞMESİ ÇERÇEVESINNDE DEVLET BÜTÇESİ}

Devlet bütçesi, genel hatlarıyla, belirli bir dönem içindeki kamu gelir ve giderlerinin önceden tahmin edildiği ve uygulandığı ekonomik, sosyal, mali ve hukuki bir doküman özelliği taşımaktadır. Bir başka ifade ile devlet bütçesi, bir ülkede otoritenin (hükümet, meclis ya da cumhurbaşkanı gibi) belli şartlar altında kamu kurumlarına fon sağlama sözü vererek anlaşmaya varmasına, taraflarının, şartlarının ve yükümlülüklerinin olmasına ve karşı1ıklı kontrollerin yapılabilmesine imkân vermesi bakımından bir sözleşmedir (Wildavsky, 1964: 2). 
Böylece devlet bütçesi, taraflarca taahhütlerin verilebildiği, yaptırımların uygulanabileceği hukuki ilişkileri doğurmasının yanı sıra ekonomik, sosyal ve mali açıdan kararların alınabilmesine aracı olmaktadır.

Jean-Jacques Rousseau, Thomas Hobbes, John Locke ve Immanuel Kant gibi düşünürler tarafından geliştirilen toplum sözleşmesi, toplum üzerinde oluşacak olan bir otoritenin ancak bireylerin kabulü ile mümkün olabileceğini ifade etmektedir. Düşünürlerin ortak noktası, siyasi bir otorite olmadığında bireylerin nasıl yaşayacaklarını ve aslında siyasi otoritenin varlığı ve yokluğu durumunda bireylerin davranışlarını sorgulamalarıdır. Onlara göre, bireylerin temel ihtiyaçlarının giderilmesinde toplumsal düzen fikri ön plandadır. $\mathrm{Bu}$ düzenin oluşması için bireylerin birbirine olan ve otoriteye olan güveni oldukça önemlidir. Nitekim Rousseau, devlette yalnız tek bir sözleşmenin var olduğunu, onun da bireylerin ortaklık sözleşmesi olduğunu vurgulamıştır (Rousseau, 2007: $155)$.

Bütçeler de, içsel süreçlerden hükümet ve vatandaş arasında belirlenen harcama ve politika taahhütlerine dönüştüklerinde özgün bir sözleşme özelliği taşımaktadır. İhtiyaç duyulan idari esneklik ve siyasal destek sürecin kilit aşamalarını oluşturmaktadır. Bu da her bütçe döneminde uygulanamadığından, bütçeler genellikle diğer sözleşmeler gibi de tam olarak değerlendirilemez. Ancak bütçelerin vatandaşlar üzerindeki etkileri belirginleştikçe sözleşmelere daha benzer özellikler taşımaları sağlanabilmektedir (Schick, 2011: 4). Özellikle mali, sosyal sözleşmeler ve performans sözleşmeleri bütçelerin vatandaş odaklı bir bütçeleme anlayışında uygulanabilmesine imkân sağlamaktadır. Bir başka ifadeyle söz konusu üç sözleşmenin varlı̆̆g, devlet bütçelerinin sözleşme niteliği taşıyıp taşımadığına ilişkin bilgi vermektedir.

\section{A. Mali Sözleșme}

Mali sözleşme, milli bütçesi olan her ulus devletin sahip olduğu bir sözleşmedir. Toplam harcamalar, bütçe açıkları, borçlar gibi mali büyüklükler ile ilgili kararların taraflarca belirlenmesi mali sözleşmenin unsurlarını oluşturmaktadır (Schick, 2011: 4). Bazı hükümetler gelir-gider dengesine ya da toplam gelir, harcama ve borçlara sınırlar koyan kuralları bütçelerinde uygulamaktadır. Mali sözleşmenin varlığı fark edilebilir olduğunda, genellikle bütçe kararlaştırılmadan önce parametreleri sabit olmaktadır. Eğer mali sözleşme bütçede yeterince açık değilse, bütçedeki parametreler bütçe kararlaştırıldıktan sonra netleşmektedir. Açık bir mali sözleşme bütçe kararlarını kısıtlarken, açık olmayan bir mali sözleşme ise o kararları sadece bünyesinde barındırmaktadır.

Günümüzde gelişmiş ve gelişmekte olan ülkelerin çoğunda açik mali düzenlemelere yönelik bir eğilim söz konusudur. Bazı ülkelerde yıllık bütçe çalışmaları sırasında mali sınırların belirlendiği görülürken, bazılarında ise ulusal düzeyde anayasa ya da yasalarında, uluslararası düzeyde ise yapılan anlaşmalarla mali sınırlamalar ile bütçe uygulamaları gerçekleştirilmektedir. Bütçenin mali sözleşme özelliğinin ön plana çıkması için mali sınırlamaların yanında yönetilebilirlik, güvenilirlik, siyasal kapasitenin düzeyi de etkili olabilmektedir. Çünkü mali sorumlulukta kamu yararının büyük bir kısmı finansal piyasaların 
davranışlarından kaynaklığı için başarılı bütçe kurallarının gözle görülür biçimde uygulanabilir ve güvenilir olması gerekmektedir (Anderson \& Minarik, 2005: 518). Bu sayede vatandaş ve siyasi otoriteler arasında -her iki tarafin amaçlarına hizmet eden- bir mali sözleşme ile bütçeleme anlayışı benimsenebilmektedir.

Bir mali sözleşmenin taşıması gereken özellikleri özetle aşağıdaki gibi siralamak mümkündür (Schick, 2011: 6-8) :

- Mali sözleşme olumsuz ekonomik ortamda vatandaşlara zarar vermeyecek şekilde düzenlenmelidir.

- Mali sözleşmede kurallar orta vadeli anlayış çerçevesinde oluşturulmalidır.

- Mali sözleşmede kurallar sıklıkla olmasa da zorlayıcı olmalıdır.

\section{B. Sosyal Sözleşme}

Sosyal sözleşme, gelir desteklerini, hukuki çerçevede düzenlenmiş transferleri ve şimdiki ve gelecekteki vergi ödeyicilerin geçmişte verdikleri taahhütleri içermektedir. $\mathrm{Bu}$ sözleşme ile vergi ödeyicilerinin farklı kişiler olmasına rağmen geçmişte vaat ettikleri vergileri gelecekte de ödemeleri beklenmektedir. Bunun karşılığında da, hükümetlerin zamanında ve doğru bir şekilde gerekli hizmetleri yerine getirmeleri beklenmektedir (Whale, 2000: 135).

Bir sosyal sözleşmenin taşıması gereken özellikleri özetle aşağıdaki gibi siralamak mümkündür (Schick, 2011: 10-12) :

- Hükümetler sosyal sözleşmede yer alan taahhütlere, risk maliyetlerini hesaba katarak yer vermelidir ve taahhütlerin uygulanabilir seviyede düzenlenmesi gereklidir.

- Gözden geçirilmiş sözleşmeler ek olarak yeniden düzenlenmemelidir.

- Sosyal sözleşme, alıcılara fayda sağlayan ya da onları olumsuz yönde etkileyen riskler arasında ayrım yapabilmelidir.

- Olumsuz ekonomik dalgalanmalar karşısında sosyal sözleşmenin dayanıklı ve sürdürülebilir olması gereklidir.

- $\quad$ Sosyal sözleşme ile hükümetler, risk ve maliyetleri paydaşlar arasında paylaşmalıdır.

Devlet bütçesi, sosyal sözleşme özelliği taşımaktadır. Sosyal bir sözleşme olarak belirlenen devlet bütçesinde taraflar, toplum ve devlet olmaktadır. Taraflarda, devleti temsilen çoğunlukla vatandaşın güveni ve seçimi ile belirlenen hükümetler ve o ülkede yaşayan vatandaşlar yer almaktadır. Sosyal sözleşme devlet bütçesi yönüyle ele alındığında, aslında tam anlamıyla bağlayıcılığı olan bir sözleşme değildir. Çünkü, hükümetler nüfus planlaması ve beklentisi veya ekonomik krizler gibi pek çok neden ile sözleşme şartlarını yasal bir şekilde değiştirebilmekte ve yorumlayabilmektedir (Schick, 2011: 8). Örneğin, kamu borcu yüksek seviyede olan bir ülkede, vergiler geçmişte taahhüt edilenden daha fazla uygulanabilir ve kamusal hizmetler tam anlamiyla gerçekleştirilemeyebilmektedir. Dolayısıyla hükümetlerin iradi uygulamaları, devlet bütçesinin sosyal sözleşme yönünü zamanla esnetebilmekte ya da değiştirebilmektedir. 


\section{Performans Sözleşmesi}

Performans sözleşmesi, bütçenin idari işlemlerinin finansmanı ve kamu hizmetlerinin temini kısımlarıyla ilgilidir. Performans sözleşmesi, bütçe girdilere odaklandığında kesinleşememekte, ancak bütçe fiili ve öngörülen sonuçlara göre şekillendiğinde kesinleşmektedir. Bütçede harcamalar girdilere göre sınıflandırılsa bile, bütçenin ilgili kalemleri performans sözleşmesi unsurlarını içermektedir.

Bütçeyi performans amaçlı bir sözleşme olarak düşünmek oldukça önemlidir. Bütçe kavramını performans sözleşmesi olarak netleştirmek için sadece performans ile ilgili olan noktaları ayırmak gerekmektedir. Bunun pek çok yolu mümkün olsa da en bilinen yöntemi, performans bütçelemeyi kaynakların tahsisi ve bilgilerin korunması ve şeffaflığı olarak ele almaktır.

Bir performans sözleşmesinin taşıması gereken özellikleri özetle aşağıdaki gibi sıralamak mümkündür (Schick, 2011: 13-17) :

- Performansın belirlenmesi ve ölçülmesi gerekmektedir.

- Performans sözleşmesi, hizmetleri ve etkinlikleri içermelidir.

- Bir performans sözleşmesinde maliyetlerin belirtilmesi gerekmektedir.

- Bir performans sözleşmesi değişim gerektirmektedir.

OECD ülkeleri kapsamında pek çok ülkede performans bütçe sınıflandırması harcama kararlarında etkili olmasa bile iş yükü, faaliyetler, hizmetler, projeler, programlar, çıktılar ya da sonuçlarda çoğu zaman etkili bir göstergedir. Az sayıda ülkede ise, performans bütçe sınıflandırması hükümetlerin bütçe kaynaklarında artış ya da azalışlarda meydana gelebilecek değişikliklerde göz önünde bulundurdukları bir gösterge niteliği taşımaktadır (OECD, 2007: 74).

Mali, sosyal ve performans sözleşmelerinin varlığı vatandaşların bütçe sürecine dahil olup olmadığını yani katılım düzeylerini de belirleyecektir. Çünkü vatandaş katılımı, hükümetlerin vatandaşları tercihleri doğrultusunda etkilemeye çalışmalarına yol açacak en temel enstrümanlardan biridir (Verba ve Nie, 1987: 102). Nitekim toplum sözleşmesi olarak devlet bütçesi uygulamasına taraf olan vatandaşın güven düzeyi değişmez ya da güvensizlik olarak sabit kalırsa, düşük güven düzeyine sahip olan kişiler, çoğu kez bütçe hakkını elinde bulunduran hükümetleri oy kullanarak değiştirebilir ve şartların iyileşmesini sağlayabilir (Lee ve Schachter: 2019: 406). Bunun yanında, bütçe uygulama kararlarında şeffaflık, hesap verebilirlik, bilgiye ulaşılabilirlik ve nüfus gibi faktörler vatandaşların hükümetlerine olan güvenini etkilemektedir. Özellikle nüfusun artması, vatandaşta aidiyet duygusunun azalmasına ve kamu harcamalarından talepleri doğrultusunda daha az faydalanmasına yol açmaktadır (Grimmelikhuijsen, 2010: 8).

Bütçe uygulamalarına vatandaş katılımı, bütçe programlarının etkin bir şekilde uygulanması anlamını da taşımaktadır. Etkinsizliğin ve vatandaş katılımının olmaması ise ilgisizlik, bilgisizlik ya da cehalet ile doğrudan ilişkili olmakla birlikte eğitim düzeyi bakımından ortalama bir vatandaşın karmaşık politikalar hakkında bilgilendirilmemesi de bütçe uygulayıcılarını belirlemede 
vatandaşı yetersiz bırakmaktadır (Crosby ve diğerleri, 1986: 172). Bu doğrultuda vatandaşın bütçe gelir ve giderlerine ilişkin bilgilendirilmesini sağlamak için hükümetlerin bilgiye kolay ve erişebilir yollar geliştirmesi oldukça önemlidir (Jordan ve diğerleri, 2016: 303).

\section{II. İLIŞKISEL SÖZLEŞME AÇISINDAN VATANDAŞ GÜVENİ VE DEVLET BÜTÇESI}

İlişkisel sözleşmeler, taraflar arasındaki kazanımlar çerçevesinde uzun dönemli yükümlülükleri kapsayan ilişkiler üzerinden gerçekleştirilmektedir (Rousseau, 1995: 91). İlişkisel sözleşmelerde tarafların yükümlülüklerini yerine getirmesi kısa vadede gerçekleştirilemediği gibi yükümlülükler net olmamakla birlikte sözleşme koşulları da değişebilmektedir (Petersitzke, 2009: 30).

Pek çok sözleşmede genellikle tarafların hakları, yükümlülükleri ve bunların yerine getirilmemesi durumunda çözüm yolları yer almaktadır. Ancak söz konusu hükümler çoğu zaman ayrıntıları içermediği için tüm anlaşmazlıkların önceden tahmin edilebilmesi ya da doğabilecek yanlış anlaşılmaların önüne geçilmesi mümkün olamamaktadır. Bu nedenle eksiklikleri olan bir sözleşme, her zaman tarafların çıkarları doğrultusunda yorumlanmaya ve kullanılmaya açık hale gelebilmektedir (Macneil, 1974: 694). Taraflar sözleşmelerdeki belirsizliklerden ya da boşluklardan yararlandığında, sözleşme düzenlendiği zamanki amaçlarından sapabilecek ya da güvenilirliğini yitirebilecektir. Devlet gelir ve giderlerini bütçe hakkı doğrultusunda uygulayan hükümetlerin ve vatandaşların taraf olduğu bir toplum sözleşmesi niteliği taşıyan devlet bütçesi de ilişkisel sözleşme niteliği taşımaktadir.

Çalışma kapsamında ele alınan mali, sosyal sözleşmeler ve performans sözleşmeleri, vatandaş ve devlet arasındaki siyasi ilişkiler üzerine kuruludur. İçlerinde ise en güçlü ilişki, sosyal sözleşmeler ile gerçekleşmektedir. Nitekim bu sözleşme ile toplum yapısı şekillenebilecek, toplumsal kuralların gelişmesi ile birlikte vergi gibi toplum bilinci gereken konularda hükümet ile halk arasında anlaşma sağlanabilecektir. Performans sözleşmelerinde, vatandaşlar devletten almayı bekledikleri hizmetleri sorgulama, denetleme ve değerlendirebilme hakkına sahip olacaktır. Mali sözleşmede ise, vatandaşların hükümete emanet ettiği bütçenin nasıl yönetildiğine dair bir ilişki söz konusudur. Literatürde ise bütçeyi ilişkisel sözleşmeler olarak düşünmek genellikle vatandaşın bütçe hakkını elinde bulunduranlara (genellikle hükümet) karşı duyduğu güven üzerinden ele alınmaktadır.

Evrensel olarak bütçe uygulamaları sırasında hükümetlere, kurumların performansını ve etkinliğini artırma, adil bir gelir dağılımı, ekonomik istikrar, ekonomik büyüme ve kalkınma gibi pek çok konuda çeşitli baskılar söz konusudur. Vatandaşlar da hükümetten gün geçtikçe daha fazla harcama yapmasını talep etmeye başlamış ve bu beklentileri bütçe uygulamalarını da etkilemiştir (Inglehart, 1997: 223). Beklentilerdeki artış, performans gelişimi ile birlikte paralellik göstermediğinde de vatandaşların hükümete olan güven düzeyinde düşüşler ortaya çıkmaktadır (Parent ve diğerleri, 2005:722). 


\section{A. Kavramsal Açıdan Güven}

Güven kavramına ilişkin literatürde pek çok tanım yer almaktadır. Güven, bazı düşünürlere göre bir durum, bir tahmin, bir çözüm metodu veya bir sistematik olgu üzerinden tanımlanabilmektedir. Nitekim güven bir başkasının niyet ve davranışlarına ilişkin savunmasızlığ 1 ve kabulünü içeren bir beklentidir. Güven yalnızca kişiler arasında gerçekleşen bir olgu değildir. Kişiler kendi aralarında güven duyabileceği gibi soyut kavramlara da güven duyabilmektedir. Söz konusu soyut kavramlara en iyi örnek ise genellikle 'sistem' olarak literatürde geçmektedir. Sisteme duyulan güven, bireylerin devlete, kurumlara, kanunlara duydukları güven anlamına gelmektedir (Lewis ve Weigert, 1985: 973).

Kişiler arası güven toplumda belirli bir zemine oturtulamadığı için kişiler üstü bir organa ihtiyaç duyulmuştur. Kişilerin bir araya gelerek ve haklarını devrederek devleti kurmaları, toplum ve devlet arasında güven diyalogunu başlatmışıtır (Tunçay, 2002: 182). Devlet veya kurumlara duyulan güven, bireysel güvenden ayrıdır. Fakat devlet ve kurumlar somut nesneler olsalar da arka planında insanlar yer almaktadır. Bu yönüyle kurumsal güveni kişilerarası güvene bağlayan şey ise sorumluluktur (Örselli ve Sipahi, 2016: 844). O halde, devlet ve kamu kurumlarında görev yapan kişilerin sorumluluğu vatandaşın güvenini inşa etmede oldukça etkilidir.

Hükümete duyulan güven ise, özellikle vergi ve harcamalar konusunda hükümet politikalarına destek sağlamada çok önemlidir (Beck, Rainey ve Traut, 1990: 73). Bunun nedeni olarak, vatandaşın hükümeti güvenilir bulduğunda desteklemesi ve daha fazla vergi vererek hükümetin faaliyetlerini genişletmesi gösterilebilmektedir (Hetherington, 2005: 51). Bu yönüyle güven, bireylerden yapması istenen ideolojik fedakârlık derecesine bağlı olarak aktive edilen kamu politikalarını desteklemek veya karşı çıkmak için bireylere net sinyaller veren bir buluşsal araç olarak hareket etmektedir (Rudolph, 2009: 148).

Şekil 1. Güven Kavramının Açılımı

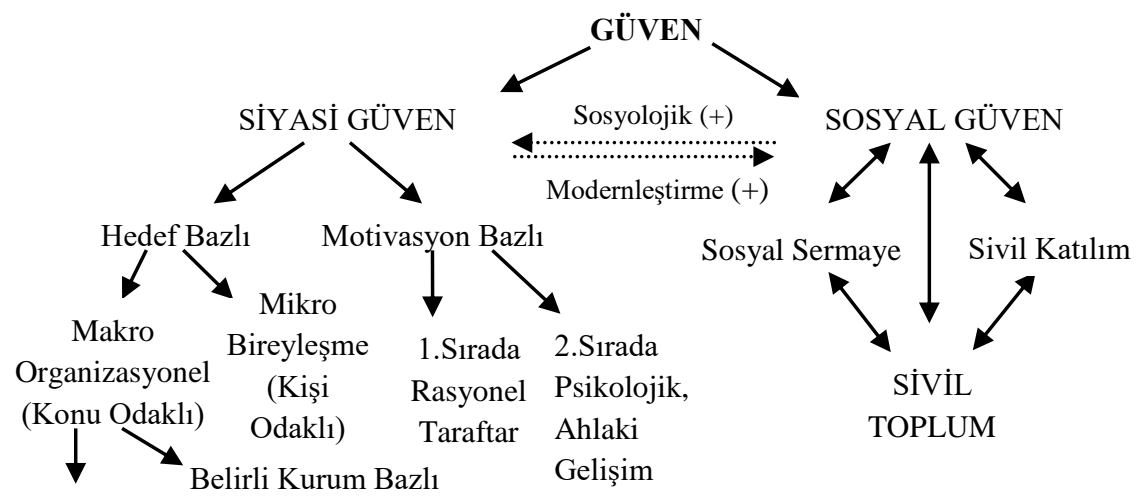

Yaygin Sistem Bazlı

Kaynak: (Blind, 2006: 8). 
Şekil 1'de görüldüğü gibi, güven kavramı, siyasi ve sosyal güven olarak iki temel kategoride ele alınabilmektedir. Siyasi güven, hedef ve motivasyon bazlı güven olarak ikiye ayrılırken, sosyal güven ise sosyal sermaye ve sivil katılım olarak ikiye ayrılmaktadır. Çalışmamıza konu olan güven kavramı ise, söz konusu şekilde siyasi güven kategorisinde yer alan makro organizasyonel hedef bazlı güvene dayalı olarak devlet ve kurumlarına yönelik olarak ele alınmıştır.

\section{B. Vatandaş Güveni ve Devlet Bütçesi İlişskisi}

Pek çok ülkenin karşılaştığı sorunlardan biri, uzun dönemli mali istikrarı gerçekleştirebilmek için kısa dönemli baskıları ortadan kaldırabilecek güven ortamının bütçe sözleşmeleri ile nasıl düzenlenmesi gerektiği sorunudur. Bu konuda kabul gören genel bir görüş, bütçe ile ilgili uygulanacak politikalar ve güven ilişkisinin kurulmasıdır (Schick, 2011: 23).

Hükümetlerin bütçe uygulamalarına duyulan güveni sağlam temellere oturtabilmesi için sözleşmelerde yerine getirmeyi taahhüt ettiği konuları hassas bir şekilde uygulaması gerekmektedir. Ancak bu sayede vatandaşın güvenini kazanabilecektir. Vatandaşlar büyük mali dengesizliklerden etkilenmediği sürece, bütçeyi yürütme görevi bulunan sisteme ya da bu sistemi elinde bulunduranlara veya kurumlara genelde güven duygusu beslemeyi tercih etmektedir. Fakat kamu kurumlarına güven soyut bir kavram özelliği taşıdığı için ölçümü ve değerlendirmesi oldukça güçtür (Gökçe, 2017: 219). Bununla birlikte vatandaşlar devlete olan güvenini belirlerken çeşitli noktalardan hareket edebilmektedir.

Vatandaşlar, hizmetleri bazında kamu kurumlarını değerlendirebilir ya da kurumların performanslarını, şeffaflığını, kurum çalışanlarının tutumlarını analiz edebilirler. Tüm bunların gerçekleşebilmesi için kamu kurumlarının faaliyetleri hakkında bilgi sahibi olunmasına imkân veren bütçelerini kamuoyu ile paylaşması ve bütçe göstergelerinin güvenilir olması esastır. Bu bağlamda, devlet ile vatandaş arasındaki güven ilişkisinin zedelenmemesi için kamu kurumlarının hukuk ve etik kurallara bağlı bir şekilde faaliyet göstermesi ve vatandaşın güvenini kazanması gerekmektedir. Dolayısıyla, bir ülkede şeffaflık ve hesap verilebilirlikten yoksun bir devlet bütçesi söz konusu ise güven ve iyi yönetişimden bahsedilememektedir (Blind, 2006: 19). Burada bahsi geçen iyi yönetişimin pek çok tanımı mevcuttur. Birleşmiş Milletler (BM) (1997) iyi yönetişimi, "bir ülkenin tüm düzeydeki işlerinin yönetiminde iktisadi, siyasi ve idari otorite kullanımı" olarak açıklamaktadır. BM, iyi yönetişimin temel ilkelerini ise, fikir birliğine odaklı, sorumlu, şeffaf, duyarlı, adil ve kapsayıc1, etkili ve verimli, hukuka dayalı ve katılımcı bir anlayış temelinde belirlemiştir (UN ESCAP, 2009: 3). Nitekim Şekil 2'de de, vatandaşın devlet ve kamu kurumlarına güveni belirleyen iyi yönetişim, BM'nin tanıma paralellik göstererek üç temel unsurla ele alınmıştır. Şekle göre, sosyal açıdan vatandaşla ilgili kurulan bağlantı, siyasi kanalda kurulan bağlantı ve ekonomik açıdan kurulan bağlantı ile iyi yönetişim çerçevesinde güven tesis edilebilmesi mümkündür. 
Şekil 2. Güven ve İyi Yönetişim İlişkisi

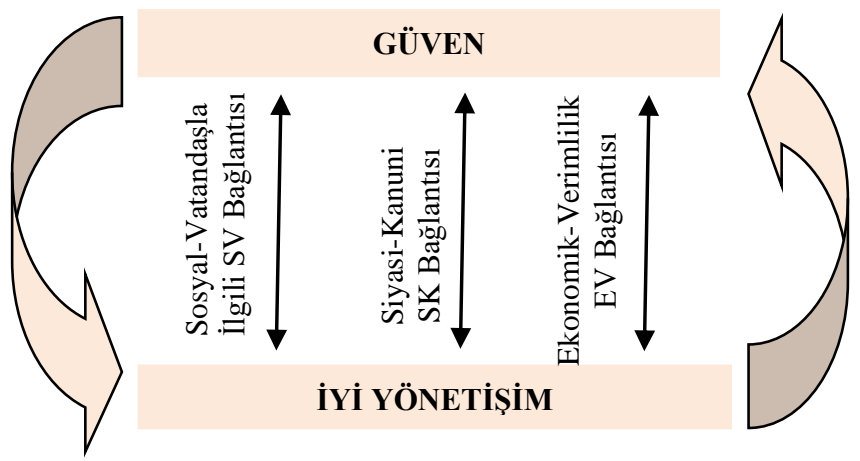

Kaynak: (Blind, 2006: 20).

Kamu kurumlarına olan güvenin sağlanabilmesi için kamu kurumlarının iyi yönetişim ve vatandaş odaklı yönetim anlayışına sahip olmaları gerekmektedir. Günümüzde pek çok ülkede performans esaslı bütçeleme yaklaşımına geçiş, iyi yönetişimin önemli bir göstergesi niteliğindedir (Ergen, 2012: 322). Dolayısıyla bütçelerin performans esaslı uygulanması, kamu kaynaklarının etkin kullanımını etkilediği gibi vatandaş memnuniyetini, kamu hizmetlerini kullananlarda tatmin düzeyini ve beklentilerini de etkilemektedir.

\section{VATANDAS GÜVENI VE DEVLET BÜTÇESI İLIŞKISISININ TÜRKIYYE VE OECD ÜLKELERİ DÜZEYINNDE DEĞERLENDİİLMESİ}

Günümüzde pek çok ülkede devlete ve kamu kurumlarına duyulan güven, devlet bütçesinde öngörülen göstergelerin tutarlılı̆̆1, şeffaflığı, açıklığ1 ve vatandaşın katılımı ile belirlenmesi gibi pek çok kritere göre gelişmektedir. Fakat dünya genelinde kamu kurumlarına olan güven yüksek seviyelerde gerçekleşmemektedir. Özellikle 1960'lı yıllardan itibaren pek çok ülkede vatandaşların devlete ve kamu kurumlarına güveninin azaldığı gözlemlenmektedir (Blind, 2007: 8). Nitekim günümüz itibariyle de bu sav geçerliliğini yitirmemiştir. 2019 yılı kamu kurumlarına küresel güven endeksi sonuçları şöyledir (Winowaton vd., 2019: https://thelivinglib.org):

“- Dünya genelinde kurumlara güvenen vatandaş yüzdesi \% 52

- Dünya çapında en güvenilir kurum Birleşmiş Milletler \% 59

- Devlete ait olmayan kuruluşlara küresel çapta güven ise \%56

- Dünya çapında vatandaşların kendi devletlerine olan güveni \%47

-Kamu kurumlarına en düşük güven duyulan ülkeler ise, Rusya (\%29),

Japonya (\%39), Ispanya (\%40), Irlanda (\%42) ve Ingiltere (\%43)"

Çalışmanın bu bölümünde, Türkiye ve OECD ülkelerinde güven ve bütçe ilişkisi, devlete, parlamentoya ve siyasi partilere güven, merkezi hükümete güven, merkezi hükümet düzeyinde performans esaslı bütçeleme uygulamalarına, kamu 
hizmetlerine güven ve hizmet kalitesine yönelik güven üzerinden çeşitli göstergeler ışı̆̆ında değerlendirilmiştir.

Tablo 1'de bazı OECD üyesi ülkelerde devlete, parlamentoya ve siyasi partilere yönelik vatandaşların güven puanlaması yer almaktadır.

Tablo 1. Seçili OECD Üyesi Ülkelerde Güven Puanlaması

\begin{tabular}{|c|c|c|c|c|c|c|c|c|c|c|c|c|}
\hline \multicolumn{5}{|c|}{ Devlete Güven } & \multicolumn{4}{|c|}{ Parlamentoya Güven } & \multicolumn{4}{|c|}{ Siyasi Partilere Güven } \\
\hline Ülkeler & ஜ্ণ & હิ & ஓ્ఠ & 을 & ஜ̊ & હે̊ & & 을 & ஜ̊ & હิ & & 을 \\
\hline Avusturya & 49 & 57 & 58 & 54 & 52 & 57 & 58 & 52 & 31 & 30 & 40 & 40 \\
\hline Belçika & 44 & 62 & 35 & 22 & 49 & 66 & 41 & 28 & 30 & 29 & 28 & 20 \\
\hline Danimarka & 55 & 67 & 61 & 60 & 74 & 85 & 75 & 72 & 51 & 40 & 58 & 49 \\
\hline Finlandiya & 68 & 75 & 54 & 49 & 67 & 77 & 60 & 55 & 37 & 26 & 32 & 30 \\
\hline Fransa & 24 & 36 & 39 & 35 & 33 & 44 & 33 & 36 & 14 & 17 & 13 & 14 \\
\hline Almanya & 27 & 49 & 45 & 32 & 35 & 51 & 46 & 39 & 18 & 18 & 24 & 19 \\
\hline Yunanistan & 40 & 41 & 25 & 25 & 47 & 53 & 33 & 23 & 22 & 21 & 15 & 9 \\
\hline Macaristan & 32 & 27 & 14 & 40 & 29 & 26 & 15 & 41 & 16 & 8 & 10 & 29 \\
\hline İrlanda & 40 & 41 & 20 & 21 & 40 & 43 & 23 & 22 & 24 & 22 & 19 & 17 \\
\hline İtalya & 29 & 37 & 25 & 25 & 35 & 39 & 27 & 26 & 19 & 16 & 19 & 18 \\
\hline Lüksemburg & 68 & 66 & 77 & 66 & 64 & 64 & 67 & 52 & 46 & 30 & 50 & 40 \\
\hline Hollanda & 40 & 73 & 56 & 47 & 53 & 77 & 56 & 54 & 35 & 35 & 41 & 45 \\
\hline Portekiz & 33 & 46 & 28 & 20 & 40 & 49 & 36 & 28 & 19 & 15 & 18 & 15 \\
\hline İspanya & 40 & 52 & 34 & 20 & 37 & 52 & 32 & 21 & 24 & 32 & 23 & 14 \\
\hline İsveç & 33 & 55 & 57 & 57 & 46 & 70 & 64 & 66 & 22 & 25 & 36 & 37 \\
\hline Türkiye & 76 & 71 & 57 & 43 & 73 & 74 & 58 & 46 & 28 & 23 & 26 & 24 \\
\hline $\begin{array}{l}\text { Birleşik } \\
\text { Krallık }\end{array}$ & 34 & 34 & 21 & 26 & 36 & 41 & 17 & 24 & 22 & 15 & 12 & 18 \\
\hline
\end{tabular}

Kaynak: European Commission - Eurobarometer, Public Opinion, https://ec.europa.eu, Erişim Tarihi: 05.07.2019).

Tablo 1'e göre, seçili OECD ülkeleri ve Türkiye'nin yer aldığı ülke grubu içinde devlete güven puanlamasında ülkeler genelinde yıllar itibarıyla bir düşüş görülmekte iken, parlamentoya ve siyasi partilere güven puanlamasında gruptaki ülkelerin yarıdan fazlasında bir artış görülmektedir. Yıllar itibarıyla devlete güven puan ortalamasında en yüksek puana sirasiyla Lüksemburg, Türkiye ve Finlandiya ülkeleri sahip olurken, en düşük puana Macaristan, Birleşik Krallık ve İrlanda ülkeleri sahip olmuştur. Yıllar itibarıyla parlamentoya güven puan ortalamasında en yüksek puana sirasıyla Danimarka, Finlandiya ve Türkiye sahip olurken, en düşük puana yine Macaristan, Birleşik Krallık ve İrlanda ülkeleri sahip olmuştur. Yıllar itibarıyla siyasi partilere güven puan ortalamasında ise en yüksek puana sirasiyla Danimarka, Lüksemburg ve Hollanda sahip olurken, en düşük puana Fransa, Macaristan, Yunanistan, Birleşik Krallık gibi ülkeler sahip olmuştur.

Şekil 3'te Türkiye'nin de içinde bulunduğu OECD üyesi ülkelerde merkezi hükümete olan güvenin 2007 yılından 2016 yılına kadarki yüzde değişim değerlerine yer verilmiştir. 


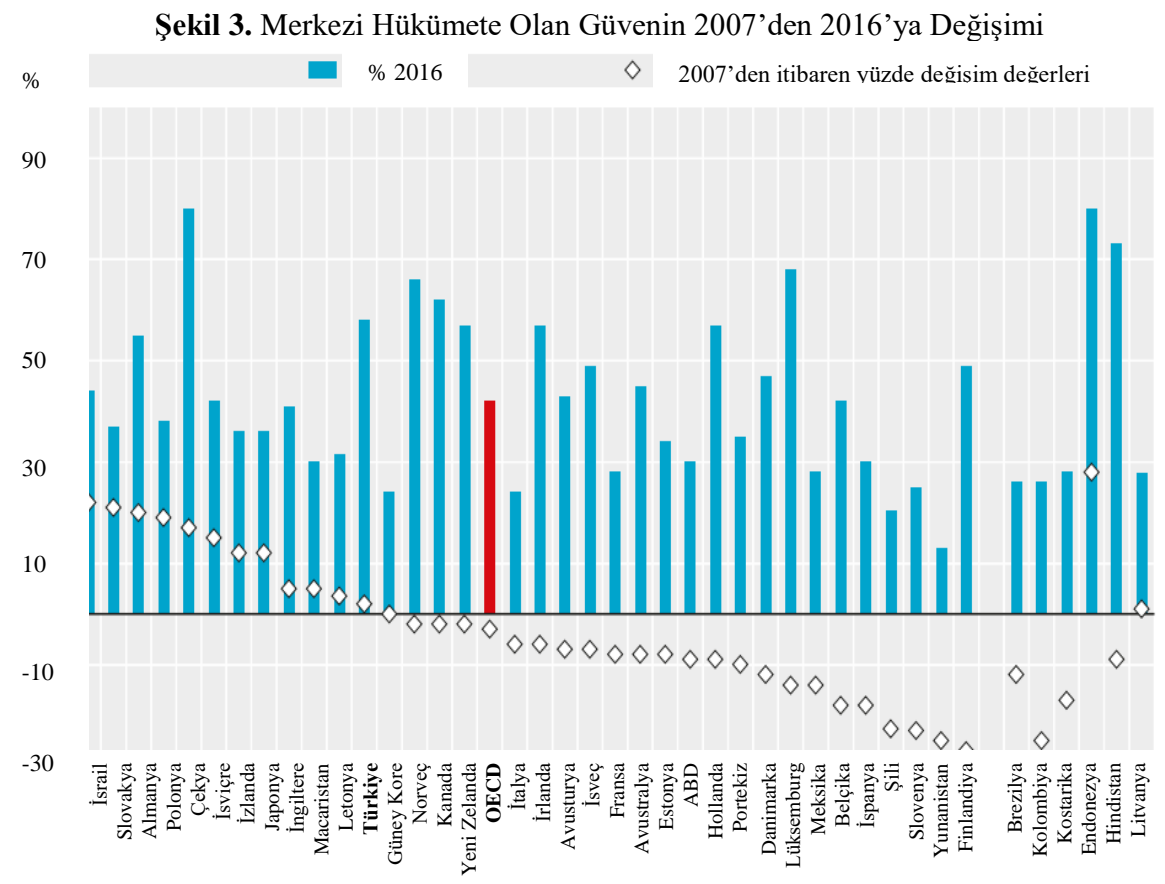

Şekil 3'e göre, 2016 verileri göz önünde bulundurulduğunda merkezi hükümete olan güveninin en yüksek olduğu OECD ülkeleri Çekya (Çek Cumhuriyeti), Lüksemburg ve Norveç’tir. Merkezi hükümete karşı en düşük seviyede güvene sahip ülkeler ise Yunanistan, Şili, İtalya ve Güney Kore'dir. 2007 yılından itibaren değişim göz önünde bulundurulduğunda ise, en yüksek artış İsrail, Slovakya ve Almanya'da görülürken, en büyük düşüş ise Slovenya, Yunanistan ve Finlandiya'da görülmüştür. Merkezi hükümete güvende 2016 yılı ortalamaları ele alındığında, Türkiye'nin OECD üyesi ülkelerin ortalamasının üzerinde olduğu ve Türkiye'nin 2007 yılına göre değişimi incelendiğinde az bir artışın gerçekleştiği görülmektedir. Bunun yanı sıra incelenen dönem itibarıyla OECD ortalamasında düşüş gerçekleşmiştir.

Devlete, hükümete ya da kurumlara güven meselesi, genelde kamu kurumlarının performansından kaynaklanan tatmin üzerinden saptanmaya çalışılmıştır. Bu nedenle de, vatandaşın güven düzeyindeki düşüşün temel nedeni olarak kamu kurumlarının performans düzeyinin düşük olması gösterilmektedir ( Turan vd, 2017: 39). Kurum performansı hakkında bilgi veren en temel unsur ise, bütçe göstergeleridir. $O$ halde kurumlara güven düzeyi, kurumların hizmet kalitesi, personelin niteliği, kamu kaynaklarının etkin kullanımı, etik ve hukuk kurallarına bağl1lık gibi pek çok hususta belirleyici olmaktadır. Vatandaş güven düzeyinin yükselmesi için merkezi hükümet düzeyinde uygulanan performans esaslı bütçeleme sistemi önem arz etmektedir. Nitekim söz konusu sistemin benimsenmesi ve doğru bir şekilde uygulanması ile kamu kurumları şeffaflık ve hesap verilebilirlik çerçevesinde faaliyet gösterebilmektedir. Şekil 4'te de Türkiye 
ve OECD üyesi ülkelerde merkezi hükümet düzeyinde performans esaslı bütçeleme uygulamaları karşılaştırmasına yer verilmiştir.

Şekil 4. Merkezi Hükümet Düzeyinde Performans Esaslı Bütçeleme Uygulamaları (2016)

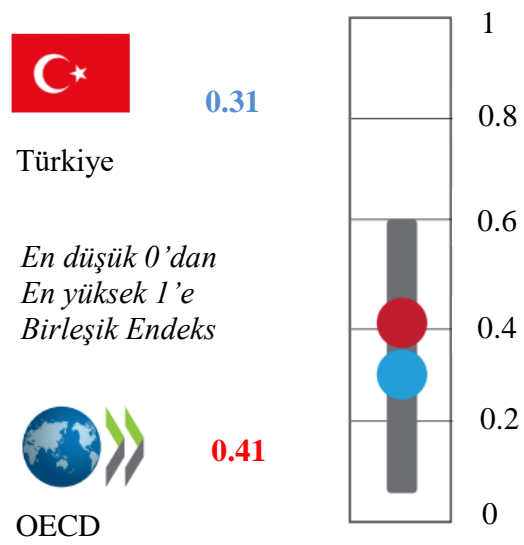

Kaynak:OECD(2016),Survey of Performance Budgeting.

Şekil 4'te yer alan merkezi hükümet düzeyinde performans esaslı bütçeleme uygulamaları başarı endeksine göre, OECD ülkeleri içinde en yüksek endeks değerinin 0.6 en düşük endeks değerinin ise yaklaşık 0.06 düzeyinde olduğu görülmektedir. Türkiye 0.31 ile 0.41 değerine sahip olan OECD ortalamasının altındadır. $\mathrm{Bu}$ da performans esaslı bütçeleme uygulamalarının Türkiye'de henüz istenilen düzeye ulaşamadığını göstermektedir.

Şekil 5'te ise Türkiye ve OECD ülkelerinde kamu hizmetlerine ilişkin güven ve memnuniyet düzeylerine çeşitli kamu hizmetleri yönüyle yer verilmiştir.

Şekil 5. Kamu Hizmetlerine Yönelik Duyulan Güven ve Memnuniyet (2016)

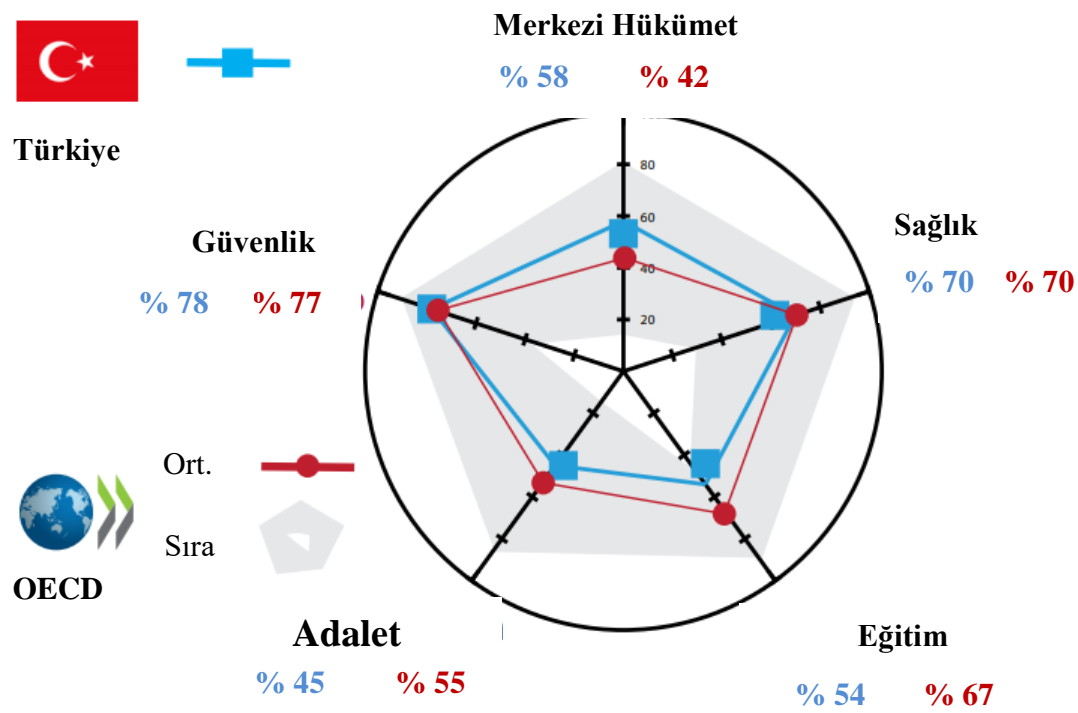


Şekil 5'e göre, 2016 yılı itibarıyla merkezi hükümete güven düzeyi \% 58 ile Türkiye'de \% 42 olan OECD ülke ortalaması üzerindedir. Sağlık hizmetlerine olan güven Türkiye ve OECD ülkelerinde $\% 70$ ile ayn düzeyde iken, eğitim hizmetlerinde olan güvende $\% 13$ fark ile, adalet hizmetlerinde olan güvende ise $\% 10$ fark ile Türkiye OECD ülke ortalamasının altında kalmıştır. Türkiye'de güvenlik hizmetlerinde güven ise OECD ortalamasının \% 1 üstündedir.

Tablo 2'de sağlık, eğitim ve adalet gibi kamu hizmetlerinde vatandaşa hizmet etme kalitesine ilişkin puan çizelgesi yer almaktadır. Tabloda yer alan hücrelerdeki sayılar, ülkelerin tüm ülkeler içindeki konumu göstermektedir. ( $\uparrow)$ işareti durumun iyileştiği, $(\rightarrow)$ işareti durumun stabil olduğu, $(\downarrow)$ işareti ise durumun kötüye gittiği hakkında bilgi vermektedir. Ülkeler, puan sıralamasına göre üç gruba ayrılmış ve her bir grup farklı renkte belirtilmiştir.

Tablo 2. Vatandaşa Hizmet Kalitesine İlişkin Puan Çizelgesi

\begin{tabular}{|c|c|c|c|c|c|c|c|c|c|}
\hline \multirow{3}{*}{ Gösterge } & \multirow{2}{*}{\multicolumn{3}{|c|}{$\begin{array}{c}\text { En İyi Seviye } \\
\text { (1'den 12'ye kadar) } \\
\text { Sağlık (Önlem ve bakımı } \\
\text { kapsamaktadır.) }\end{array}$}} & \multicolumn{3}{|c|}{$\begin{array}{c}\text { Orta Seviye } \\
\text { (13'den 23'e kadar) }\end{array}$} & \multicolumn{3}{|c|}{$\begin{array}{c}\text { En Düşük Seviye } \\
\text { (24'den 35'e kadar) }\end{array}$} \\
\hline & & & & & Eğitim & & & Adalet & \\
\hline & $\begin{array}{l}\text { Ölüm } \\
\text { Oran1- } \\
\text { Akut } \\
\text { Miyok } \\
\text { ard } \\
\text { Damar } \\
\text { Tikanı } \\
\text { klı̆ı } 1 \\
\text { (Kalp } \\
\text { Krizi) } \\
\end{array}$ & $\begin{array}{l}\text { Ölüm } \\
\text { Oranı - } \\
\text { Serebrova } \\
\text { sküler } \\
\text { Hastalık } \\
\text { (Felç) }\end{array}$ & $\begin{array}{l}\text { Kadınlard } \\
\text { a Meme } \\
\text { Kanserind } \\
\text { en Ölüm } \\
\text { Oranı }\end{array}$ & $\begin{array}{l}\text { Fen } \\
\text { Bilimlerin } \\
\text { de PISA } \\
\text { ortalama } \\
\text { puanı }\end{array}$ & $\begin{array}{l}\text { Matematik } \\
\text { te PISA } \\
\text { ortalama } \\
\text { puanı }\end{array}$ & 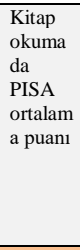 & $\begin{array}{l}\text { Etkin Yarg1 } \\
\text { Uygulamal } \\
\text { ar1 }\end{array}$ & $\begin{array}{l}\text { Hükümeti } \\
\text { n } \\
\text { Baskısınd } \\
\text { an Uzak } \\
\text { Yargılam } \\
\text { a }\end{array}$ & $\begin{array}{l}\text { Kişisel } \\
\text { şikayetleri } \\
\text { ni şiddete } \\
\text { başvurmad } \\
\text { an çözenler }\end{array}$ \\
\hline Avustralya & $15 \uparrow$ & $\begin{array}{ll}8 & \uparrow \\
\end{array}$ & $10 \uparrow$ & $\begin{array}{ll}8 & \downarrow \\
\end{array}$ & $18 \downarrow$ & 13 & 10 & 5 & 12 \\
\hline Avusturya & $20 \uparrow$ & $9 \uparrow$ & $19 \uparrow$ & $20 \downarrow$ & 15 & 25 & 5 & 10 & 6 \\
\hline Belçika & $14 \uparrow$ & $12 \uparrow$ & $31 \uparrow$ & 14 & $10 \downarrow$ & 17 & 11 & 12 & 13 \\
\hline Kanada & $18 \uparrow$ & $\begin{array}{ll}3 & \uparrow \\
\end{array}$ & $15 \uparrow$ & 4 & $\begin{array}{ll}5 & \downarrow \\
\end{array}$ & 1 & 13 & 6 & 5 \\
\hline Şili & $27 \uparrow$ & $26 \uparrow$ & $5 \rightarrow$ & 33 & 33 & 32 & 18 & 22 & 28 \\
\hline Çekya & $26 \uparrow$ & $29 \uparrow$ & $12 \uparrow$ & $23 \downarrow$ & $21 \downarrow$ & 24 & 16 & 14 & 4 \\
\hline Danimarka & $10 \uparrow$ & $18 \uparrow$ & $35 \uparrow$ & 15 & 7 & 15 & 8 & 3 & 3 \\
\hline Estonya & $7 \uparrow$ & $20 \uparrow$ & $17 \rightarrow$ & 2 & 4 & $4 \uparrow \uparrow$ & 19 & 13 & 14 \\
\hline Finlandiya & $29 \uparrow$ & $22 \uparrow$ & $7 \uparrow$ & $3 \downarrow$ & $8 \quad \downarrow$ & $2 \downarrow$ & 6 & 7 & 2 \\
\hline Fransa & $1 \uparrow$ & $11 \uparrow$ & $23 \uparrow$ & 21 & 19 & 16 & 15 & 19 & 22 \\
\hline Almanya & $21 \uparrow$ & $10 \uparrow$ & $25 \uparrow$ & 10 & 11 & 9 & 3 & 4 & 11 \\
\hline Yunanistan & $30 \uparrow$ & $32 \uparrow$ & $18 \uparrow$ & $32 \downarrow$ & $32 \downarrow$ & 31 & 26 & 25 & 25 \\
\hline Macaristan & $31 \uparrow$ & $33 \uparrow$ & $30 \uparrow$ & $28 \downarrow$ & $28 \downarrow$ & 30 & 25 & 26 & 10 \\
\hline İzlanda & $28 \uparrow$ & $21 \uparrow$ & $29 \rightarrow$ & $29 \downarrow$ & 24 & 27 & n.a. & n.a. & n.a. \\
\hline İrlanda & $32 \uparrow$ & $16 \uparrow$ & $34 \uparrow$ & 13 & 13 & 3 & n.a. & n.a. & n.a. \\
\hline İsrail & $3 \uparrow$ & $4 \uparrow$ & $33 \uparrow$ & $30 \uparrow$ & 30 & $29 \uparrow$ & n.a. & n.a. & n.a. \\
\hline İtalya & $11 \uparrow$ & $24 \uparrow$ & $20 \uparrow$ & 27 & $23 \uparrow$ & $26 \uparrow$ & 27 & 20 & 26 \\
\hline Japonya & $2 \uparrow$ & $17 \uparrow$ & $4 \rightarrow$ & 1 & 1 & 6 & 4 & 15 & 7 \\
\hline Kore & $5 \uparrow$ & $25 \uparrow$ & $1 \rightarrow$ & 5 & $2 \downarrow$ & $5 \downarrow$ & 9 & 17 & 19 \\
\hline Letonya & $24 \uparrow$ & $35 \uparrow$ & $21 \uparrow$ & 25 & 27 & 23 & n.a. & n.a. & n.a. \\
\hline Lüksemburg & $8 \uparrow$ & $6 \uparrow$ & $24 \rightarrow$ & 26 & 26 & 28 & n.a. & n.a. & n.a. \\
\hline Meksika & $35 \downarrow$ & $19 \uparrow$ & $3 \rightarrow$ & 35 & 35 & 35 & 28 & 27 & 27 \\
\hline Hollanda & $9 \uparrow$ & $13 \uparrow$ & $28 \uparrow$ & $11 \downarrow$ & $6 \downarrow$ & 12 & 7 & 1 & 16 \\
\hline Yeni Zelanda & $33 \uparrow$ & $23 \uparrow$ & $22 \uparrow$ & $6 \downarrow$ & $16 \downarrow$ & 8 & 14 & 11 & 9 \\
\hline Norveç & $23 \uparrow$ & $11 \uparrow$ & $9 \uparrow$ & $18 \uparrow$ & 14 & $7 \uparrow$ & 1 & 2 & 8 \\
\hline Polonya & $12 \uparrow$ & $27 \uparrow$ & $16 \rightarrow$ & 16 & 12 & 10 & 20 & 21 & 17 \\
\hline Portekiz & $13 \uparrow$ & $28 \uparrow$ & $11 \uparrow$ & $17 \uparrow$ & $22 \uparrow$ & $18 \uparrow$ & 23 & 16 & 24 \\
\hline Slovakya & $22 \uparrow$ & $34 \uparrow$ & $27 \rightarrow$ & $31 \downarrow$ & $29 \downarrow$ & 33 & n.a. & n.a. & n.a. \\
\hline Slovenya & $19 \uparrow$ & $30 \uparrow$ & $32 \rightarrow$ & 7 & 9 & 11 & 21 & 24 & 20 \\
\hline İspanya & $6 \uparrow$ & $7 \uparrow$ & $6 \uparrow$ & 24 & 25 & $21 \uparrow$ & 22 & 23 & 21 \\
\hline
\end{tabular}


Ayşe Atılgan Yaşa \& Kâmil Tüğen / Illişkisel Sözleşmeler Bağlamında Vatandaş Güveni Ve Devlet Bütçesi. Oecd Ülkeleri Ve Türkiye Karşılaştırması

\begin{tabular}{|l|c|c|c|c|c|c|c|c|c|}
\hline İsveç & $25 \uparrow$ & $14 \uparrow$ & $8 \uparrow$ & 22 & 17 & 14 & 2 & 8 & 1 \\
\hline İsviçre & $4 \uparrow$ & $2 \uparrow$ & $14 \uparrow$ & 12 & 3 & 22 & n.a. & n.a. & n.a. \\
\hline Türkiye & $34 \uparrow$ & $31 \rightarrow$ & $2 \uparrow$ & 34 & 34 & $34 \downarrow$ & 24 & 28 & 23 \\
\hline $\begin{array}{l}\text { Birleşik } \\
\text { Krallik }\end{array}$ & $17 \uparrow$ & $15 \uparrow$ & $26 \uparrow$ & 9 & 20 & 19 & 12 & 9 & 15 \\
\hline ABD & $16 \uparrow$ & $5 \uparrow$ & $13 \uparrow$ & 19 & 31 & 20 & 17 & 18 & 18 \\
\hline
\end{tabular}

Kaynak: OECD (2017), Government at a Glance 2017, OECD, Paris.

Tablo'ya göre Türkiye, sağlık hizmetlerinde OECD ülkeleri içinde kalp krizinden ve felçten kaynaklanan ölümleri önlemede en düşük seviyede ve son sıralarda yer alırken meme kanserinden kaynaklanan ölümleri önlemede ise en iyi seviyede ve üst siralardadır. Ülkemiz eğitim hizmetlerinde, fen, matematik ve kitap okumada PISA ortalama puanı bazında OECD ülkeleri içinde en son sıradaki Meksika'dan önce yer almaktadır. Adalet hizmetlerinde ise, etkin yargılama uygulamaları, hükümet baskısından uzak yargılama ve şiddete başvurmadan şikâyette bulunma açısından OECD ülkeleri içinde en düşük seviyede ülke grubunda yer almaktayı.

\section{SONUÇ}

Demokratik toplumlarda hükümetler, siyasi partiler ve kamu kurumları meşruiyetini halk egemenliğinden almaktadır. Yönetenler, vatandaşların oyları ile belirlenmekte, vatandaşın güveni ve desteği devam ettiği sürece görevlerini yerine getirmektedirler. Yürütme gücünü elinde bulunduran parti bütçe yapma hakkına da sahip olduğu için vatandaşın güveni doğrultusunda bu sorumluluğu en iyi şekilde yerine getirebilmeyi taahhüt etmiş olmaktadır. Bu bağlamda güven, vatandaşların bütçe uygulamalarını dolaylı olarak belirleyen önemli bir faktördür. Güven, aynı zamanda taraflara haklar ve ödevler yüklediği ve karşı tarafın davranışlarını da şekillendirdiği için bütçe ile iliş̧isel bir sözleşme niteliği taşımaktadır. Dünya genelinde pek çok ülkede son zamanlarda devlete, hükümete, parlamentoya, kamu kurumlarına ve kamu görevlilerine duyulan güvende ciddi azalmalar gözlenmektedir. Bunun pek çok nedeninin olduğu ise OECD, Avrupa Birliği gibi örgütlerin anket çalışmalarında görülmüştür. Temel neden olarak ise, kamu kurumlarının performansı gösterilmektedir.

Çalışmamız kapsamında, OECD veri setinden yararlanarak çeşitli göstergeler ile OECD üyesi ülkeler ve Türkiye karşılaştırması yapılmıştır. İlk olarak yapılan karşılaştırma sonucunda, seçili OECD ülkeleri ve Türkiye'nin yer aldığı ülke grubu içinde devlete güven puanlamasında ülkeler genelinde yıllar itibarıyla bir düşüş görülmekte iken, parlamentoya ve siyasi partilere güven puanlamasında gruptaki ülkelerin yarıdan fazlasında bir artış görülmektedir. Türkiye ve OECD ülkelerinde devlete ve kurumlara güven düzeyleri karşılaştırıldığında, ekonomik yönden ileri seviyede olan Birleşik Krallık, Almanya ve Fransa gibi ülkelerin aralarında bulunduğu pek çok ülkede devlete ve kurumlara güven düzeyi OECD ortalaması ve Türkiye'ye göre gerilerdedir. Türkiye'de siyasal güven olarak ele alabileceğimiz güven düzeyi OECD üyesi ülke grubunda üst seviyelerdedir. Bu durum Türkiye'de bütçe hakkını elinde bulunduranlara karşı güven düzeyinin yüksekliğinden hareketle, bütçe uygulamalarına güven düzeyinin yüksek olduğu sonucunu da doğurabilmektedir. Bir diğer ifade ile Türkiye' de vatandaşlar kamu kurumlarının bütçe performansına 
OECD ülke ortalamasından daha fazla güvenmekte ya da Türkiye'de yürütme gücüne güven düzeyi OECD ülke ortalaması üzerindedir denilebilmektedir.

Türkiye ve OECD üyesi ülkelerde merkezi hükümete olan güvenin 2007 yılından 2016 y1lına kadarki yüzde değişim değerleri incelendiğinde ise, merkezi hükümete olan güveninin en yüksek olduğu OECD ülkelerin Çekya, Lüksemburg ve Norveç olduğu görülmektedir. Merkezi hükümete karşı en düşük seviyede güvene sahip ülkeler ise Yunanistan, Şili, İtalya ve Güney Kore'dir. 2007 yılından itibaren değişìm göz önünde bulundurulduğunda ise, en yüksek artış İsrail, Slovakya ve Almanya'da görülürken, en büyük düşüş ise Slovenya, Yunanistan ve Finlandiya'da görülmüştür. Merkezi hükümete güvende 2016 yılı ortalamaları ele alındığında, Türkiye'nin OECD üyesi ülkelerin ortalamasının üzerinde olduğu ve Türkiye'nin 2007 yılına göre değişimi incelendiğinde, az bir artışın gerçekleştiği görülmektedir. Bunun yanı sıra incelenen dönem itibarıyla OECD ortalamasında düşüş gerçekleştiği sonucuna ulaşılmıştır.

Türkiye ve OECD üyesi ülkelerde merkezi hükümet düzeyinde performans esaslı bütçeleme uygulamaları başarı endeksine göre, OECD ülkeleri içinde en yüksek endeks değerinin 0.6 en düşük endeks değerinin ise yaklaşık 0.06 düzeyinde olduğu görülmektedir. 0.31 değerine sahip olan Türkiye, 0.41 olan OECD ortalamasının altındadır. $\mathrm{Bu}$ da performans esaslı bütçeleme uygulamalarının Türkiye'de henüz istenilen düzeye ulaşamadığını göstermektedir.

Türkiye ve OECD ülkelerinde kamu hizmetlerine ilişkin güven ve memnuniyet düzeyleri çeşitli kamu hizmetleri yönüyle ele alındığında, 2016 yılı itibarıyla merkezi hükümete güven düzeyi \% 58 ile Türkiye'de, $\% 42$ olan OECD ülke ortalaması üzerindedir. Sağlık hizmetlerine olan güven Türkiye ve OECD ülkelerinde $\% 70$ ile aynı düzeyde iken, eğitim hizmetlerinde olan güvende $\% 13$ fark ile adalet hizmetlerinde olan güvende ise $\% 10$ fark ile Türkiye OECD ülke ortalamasının altında kalmıştır. Türkiye'de güvenlik hizmetlerinde güven ise OECD ortalamasının \% 1 üstünde gerçekleşmiştir.

Sağlık, eğitim ve adalet gibi kamu hizmetlerinde vatandaşa hizmet etme kalitesine ilişkin puan çizelgesi incelendiğinde, Türkiye'nin sağlık hizmetlerinde OECD ülkeleri içinde kalp krizinden ve felçten kaynaklanan ölümleri önlemede en düşük seviyede ve son sıralarda, meme kanserinden kaynaklanan ölümleri önlemede ise en iyi seviyede ve üst sıralarda yer aldığı görülmektedir. Türkiye eğitim hizmetlerinde, fen, matematik ve kitap okumada PISA ortalama puanı bazında OECD ülkeleri içinde en son sıradaki Meksika'dan önce yer almaktadır. Adalet hizmetlerinde ise Türkiye, etkin yargılama uygulamaları, hükümet baskısından uzak yargılama ve şiddete başvurmadan şikâyette bulunma açısından OECD ülkeleri içinde en düşük seviyede ülke grubunda yer almaktadır.

Ülkemizde 21.1.2017 tarih ve 6771 sayılı kanunla yapılan ve 16.4.2017 tarihindeki referandumla kabul edilen 18 maddelik Anayasa değişikliği ile Cumhurbaşkanlığı Hükümet Sistemi getirilmiş, 1982 Anayasasının Mali ve Ekonomik Hükümlerinde bazı değişiklikler olmuştur. Yeni sistemde TBMM'ye bütçe kanun teklifini Cumhurbaşkanı sunacaktır. Değişikliklerin normal şartlarda 3 Kasım 2019 Genel ve Cumhurbaşkanlığı seçimleri sonrası yürürlüğe girmesi 
söz konusu iken TBMM'nin genel seçimlerin yenilenmesine ve seçimin 24 Haziran 2018 Pazar günü yapılmasına ilişkin 20.4.2018 tarih ve 1183 sayılı kararının 20.4.2018 tarih ve 30397 mükerrer sayılı Resmi Gazetede yayınlanmasıyla birlikte Anayasa değişiklikleri 24 Haziran 2018 seçimleri sonrası yürürlüğe girmiştir. Cumhurbaşkanlığı Hükümet Sistemiyle yürütme gücü Cumhurbaşkanlığında toplanmıştır. Bütçe sürecini de doğrudan etkileyen söz konusu bu uygulama henüz yeni olduğu için, Türkiye'de yürütme gücünün güven düzeyi üzerindeki etkilerini saptamak adına zamana ihtiyaç vardır.

Tüm bu yorumlara rağmen güven duygusu, süreklilik arz etmeyen ve başka değişkenlerden çok kısa bir sürede etkilenen bir olgu olması nedeniyle, mali, ekonomik, siyasi ve sosyal açıdan karşılaşılan bir olumsuzluk neticesinde güvensizliğe kolayca dönüşebilecektir. Siyasi güven dolayısıyla ekonomik ve mali göstergelere duyulan güven, sosyal hayattaki diğer gelişmeler ile desteklenmedikçe kırılgan bir yapıya sahip olacağından, tek başına belirleyici olamamakla beraber, göz önünde bulundurulması gereken önemli bir göstergedir.

\section{KAYNAKÇA}

Almond, G.A. (1998), "The return to the state", American Political Science Review, 82 (3), 853-874.

Anderson, B., Minarık, J. J. (2005), “Design Choices for Fiscal Policy Rules”, OECD Journal on Budgeting, 5(4), 513-555.

Beck, P. A.; RaIney, H. G.; Traut, C. (1990). "Disadvantage, disaffection, and race as divergent bases for citizen fiscal policy preferences". The Journal of Politics, 52(1), 71-93.

Blind, P. K. (2006), Building Trust in Government in the Twenty - First Century: Review of Literature and Emerging Issues, 7th Global Forum on Reinventing Government Building Trust in Government 26-29 June 2007, Vienna, Austria.

Crosby, N., Kelly, J. M., \& Schaefer, P. (1986). Citizens panels: A new approach to citizen participation. Public administration review, 170-178.

Dinler, D. (2003), “Türkiye'de Güçlü Devlet Geleneği Tezinin Eleştirisi”, Praksis, 9, ss. 17-54.

Ergen, Z. (2012), "Yönetimden yönetişime: Katılımcı bütçeleme modeli". Maliye Dergisi, 163, 316334.

European Commission - Eurobarometer, (2019), Public Opinion, https://ec.europa.eu, (05.07.2019).

Gallup World Poll, (2019), https://www.gallup.com, (15.07.2019).

Grimmelikhuijsen, S. G. (2010). Transparency of Public Decision-Making: Towards Trust in Local Government?. Policy \& Internet, 2(1), 5-35.

Gökçe, G. (2007), Güçlü ve Zayıf Devlet Tartışmaları Bağlamında Türkiye. Çizgi Kitabevi.

Hetherington, M. J. (2005). Why trust matters: Declining political trust and the demise of American liberalism. Princeton, NJ: Princeton University Press.

Inglehart, R. (1997). Postmaterialist values and the erosion of institutional authority. In J. S. Nye (Ed.), Why people don't trust government (pp. 217-236). Cambridge, MA7 Harvard University Press.

Jordan, M., Yusuf, J. E. W., Mayer, M., \& Mahar, K. (2016). What citizens want to know about their government's finances: Closing the information gap. The Social Science Journal, 53(3), 301-308.

Lee, Y., Schachter, H. L. (2019). Exploring the relationship between trust in government and citizen participation. International Journal of Public Administration, 42 (5), 405-416.

LewIs, J. D.; Weigert, A. (1985). "Trust as a social reality", Social forces, 63(4), 967-985.

Macneil, I. R. (1974), "The Many Futures of Contracts", Southern California Law Review, Vol. 47, 691-816.

OECD (2007), Performance Budgeting in OECD Countries, OECD Publishing, Paris. 
OECD (2017), Government at a Glance 2017, OECD, Paris.

Örselli, E.; Sipahi E. B. (2016), “Türkiye'de Vatandaşların Kamu Kurumlarına Güveni”, Journal of International Social Research, 9 (45), 843-850.

Parent, M., Vandebeek, C. A., Gemino, A. C. (2005). Building citizen trust through egovernment. Government Information Quarterly, 22(4), 720-736.

Petersitzke, M. (2009) Supervisor Psychological Contract Management, Wissenschaft, Germany, Gabler Edition.

Rousseau, D.M. (1995), Psychological Contracts in Organizations: Understanding Written and Unwritten Agreements, Thousand Oaks, Sage Publications.

Rousseau, J. J., Günyol, V. (2007). Toplum sözleşmesi. Türkiye İş Bankası Kültür Yayınları.

Rudolph, T.J. (2009), "Political trust, ideology, and public support for tax cuts". Public Opinion Quarterly, 73(1), 144-158.

Schıck, A.(2011), "Repairing the Budget Contract between Citizens and the State", OECD Journal on Budgeting, Vol. 11/3.

Tunçay, M. (2009). Batı'da Siyasal Düşünceler Tarihi Seçilmiş Yazılar Yeni Çă̆. 3. Baskı. İstanbul: Bilgi Üniversitesi.

UN ESCAP (2009), What is Good Governance?, https://www.unescap.org/, (10.07.2019).

Verba, S., \& Nie, N. H. (1987). Participation in America: Political democracy and social equality. Illinois, IL: University of Chicago Press.

Wang, X., Wan Wart, M. (2007). When public participation in administration leads to trust: An empirical assessment of managers' perceptions. Public Administration Review, 67(2), 265278.

Whale, J. (2000), Edmund Burke's Reflections on the Revolution in France, Manchester University Press, USA.

Wildavsky, A. (1964), The Politics of the Budgetary Process, Little, Brown and Company, Boston.

Winowaton, M.; Zahuranec, A J. ; Young, A.; Verhulst, S. (2019), Index: Trust in Institutons 2019, https://thelivinglib.org,(15.07.2019).

\section{SUMMARY}

The government budget is a contract that provides economic, social and financial decisions as well as creating legal relations where commitments can be made and sanctions can be applied by the parties. Citizens are required to provide political support when the government and public institutions have to support administrative flexibility with government budget. Since this situation cannot be implemented in every budget period, budgets cannot be considered as a full contract. However, budgets'effects become more evident, they can be provided with similar features to contracts. In particular, financial, social and performance contracts enable budgets to be implemented in a citizen-oriented budgeting approach. Among them, the most powerful relationship is realized through social contracts. As a matter of fact, the structure of the society can be shaped with this agreement and an agreement can be reached between the government and the public on issues that require social awareness such as tax with the development of social rules. In performance contracts, citizens will have the right to question, inspect and evaluate the services they expect from the government. In the fiscal agreement, there is a relationship of how the budget entrusted to the government by the citizens is managed.

Trust in government or institutions is separate from individual trust. However, the government and institutions are concrete objects, people stand in the background. In this respect, the responsibility connects institutional trust to 
interpersonel trust. The responsibility of those working in government and public institutions is therefore very effective in building the trust of the citizen. Today, the trust in the government and public institutions in many countries is developing according to many criteria such as consistency, transparency, openness and determination of the indicators envisaged in the government budget. However, trust in public institutions around the world is not high. The reason for this is the performance of public institutions.

In our study, comparisons are made for OECD countries and Turkey in the light of various indicators. The first is the ratings of citizens' confidence in the state, parliament and political parties in some OECD member countries. Trust to the government score decline over the years in OECD countries and Turkey, while observed trust on parliament and political parties increase of more than half of the countries. The other comparison concerns trust in the central government. In this regard, considering the average of OECD countries in 2016, Turkey is above average and when compared to changed from 2007, it is seen that the slight increase. Another one is index of success that the implementation of performancebased budgeting at central government levels in Turkey and OECD member countries. Accordingly, the highest index value among OECD countries is 0.6 and the lowest index value is about 0.06. Turkey is below (0.31) the OECD average (0.41). Another, confidence and satisfaction levels are related to the public service in Turkey and OECD countries. As of 2016, the central government in Turkey with \% 58 confidence level is above OECD average of $\% 42$. While the same level of confidence with $\% 70$ in Turkey and OECD countries for health services, the difference with \% 13 confidence that the justice of confidence in educational services remained below the OECD average, with a \% 10 difference. The confidence in the security services in Turkey was $\% 1$ above the OECD average. Finally, the scorecard on the quality of serving the citizen in public services such as health, education and justice was examined. Turkey is at the lowest levels in the OECD group of countries in health care and in the last row; in education services science, math, reading books at the average score PISA before Mexico that place in the last of OECD countries, while the justice services at the lowest levels in the OECD countries group. 